\title{
PELI ON KULTTUURIA, KULTTUURI PELIÄ
}

Hauskanpitoa, ajanvietettä, sosiaalisuutta, yksinäisyyden tunteen torjuntaa, jännitystä, riemua, surua, riskejä, taloutta, teollisuutta, identiteettejä, politiikkaa, voittamista, tappioita, järkeä, tunteita, leikkiä, vakavaa - pelaaminen on kaikkea tätä, usein yhtä aikaa useampaa näistä. Pelaaminen on erottamaton osa kulttuuriamme, mistä kertovat viimeistään metaforiset rinnastukset elämän ja pelin välillä. Puhumme puoli-ironisesti "pelisäännöistä", vaikka tosiasiassa puhumme sosiaalisista tilanteista, jotka koskevat oikeaa elämää. Tämä johtuu siitä, että yritämme sulkeistaa jonkin yhteisön tai sosiaalisen elämän rakenteen pelin kaltaiseksi tilanteeksi, jossa on olevinaan sääntökirja, joka jättää mahdollisimman vähän tulkinnanvaraa sille, miten voimme toimia ilman konflikteja ja väärinymmärryksiä. Jäsennämme yhteiskuntaa ja kulttuuria mediaalisesti, mistä toinen esimerkki ovat teatterimetaforat, kuten "sukupuolirooli". Me huomaamme "pelaavamme roolia", kuten asian voi ruotsinkielisestä idiomista mekaanisesti kääntäen todeta. Pelaamista voi, ja pitää, pohtia ja tutkia nimenomaan peleistä ja pelikulttuureista käsin, sillä niiden merkitys on vain kasvussa. Peli on kulttuuria, kulttuuri peliä.

Tämän Lähikuvan teemanumeron aiheena ovat pelikulttuurit. Ei ole sattumaa, tai pikemminkin on paljon kertovaa, että kaikki artikkelit, monipuolisista aiheistaan ja näkökulmistaan huolimatta, käsittelevät digitaalista pelaamista. Sitä tutkitaan Suomessa - toki muun pelaamisen ohella - nykyään runsaasti, monitieteisesti ja kansainvälisesti, mistä tämän numeron artikkelitkin kertovat. Artikkelien kautta avautuu näkökulmia, jotka kertovat asioita kulttuuristamme, joista emme ehkä muuten olisi tietoisia. Kulttuurimme on lopulta peliä, pelisääntöjä ja joskus niiden rikkomista tai ainakin haastamista. Siksi artikkelien aiheet ovat niin tärkeitä, omien itsessään tärkeiden aiheidensa ulkopuolella. Yliopistoissamme on digitaalisuuteen ja pelaamiseen keskittyneitä koulutusohjelmia. Suomalaisten peliyhtiöiden menestys maailmalla on huikeaa, samoin alati kasvavan e-urheilun. Tuntematta tilannetta tarkemmin voi toivoa, että synergia suunnittelun, pelaamisen ja tutkimuksen välillä syvenee ja verkottuu kansainvälisesti. Se on koko Suomen etu, eikä pelkästään taloudellisista näkökohdista.

Digipelit ovat lähes kirjaimellisesti kaikkialla, sillä kannamme niitä, lapsista ikääntyneempään väestöön, älypuhelimiemme mukana. Meidän ei tarvitse lähteä minnekään pelaamaan, vaan se on mahdollista minä hetkenä hyvänsä, 
ja internet mahdollistaa monipelaamisen ympäri maailmaa yhtä hyvin kotisohvalla kuin ruuhkabussissa. Perinteisemmät pelit lautapeleistä jalkapallon potkimiseen eivät ole hävinneet minnekään, mutta silkka vaivattomuus tekee digipelaamisesta entistä suositumpaa - unohtamatta pelaamisen koukuttavuutta joskus rasitteeseen asti. Koukuttava digipelaaminen koskee myös raha(uhka)pelejä, kun lotota tai vetoa voi lyödä hetken mielijohteesta ilman kävelemistä räntäsateessa kioskille. Tämä kaikki on pelikulttuuria.

Tilastokeskuksen Digipelaaminen 2017 -tutkimuksen mukaan digitaalisten pelien pelaaminen on Suomessa nelinkertaistunut 25 vuodessa, eli 1990-luvun alusta. Asiaa on tutkittu myös 2002. Tarkastelujaksolla vähintään kerran vuodessa pelaaminen on kasvanut 13 prosentista 55 prosenttiin. Tutkimuksen yleisjohtopäätös on, että digipelaaminen on "yleistä koko väestön keskuudessa", eikä se ole "enää vain lasten- tai nuorisokulttuuria", vaikka aktiivisin ryhmä on edelleen 10-14-vuotiaat pojat. Suurinta kasvu on vertailuvälillä ollut yli 44-vuotiaiden keskuudessa. Kysymys on laajemmin vapaa-ajasta. Saman tutkimuksen mukaan musiikin kuuntelu on vähentynyt vastaavalla tarkkailuvälillä. (Tilastokeskus 2019.)

Tutkimus toteaa, että uudempien pelien ohella vanhat pelit, kuten pasianssi, ovat säilyttäneet suosionsa etenkin vanhemmissa ikäryhmissä, mihin yhtenä syynä on ollut tietokoneen yleistyminen näiden keskuudessa. Mobiilipelit taas ovat korostuneesti nuorempien ikäryhmien keskeisin pelityyppi. (Ibid.) Näin varmasti on, mutta on syytä ottaa huomioon historialliset jatkuvuudet pelaamisen kehitystä arvioitaessa. Tämän päivän yli 40-vuotiaat edustivat nuorempia tutkimuksen ikäryhmiä 1990-luvun alussa ja 2002.

Otan esimerkiksi itseni: vuonna 1991 olin 18-vuotias, nyt olen 47. Digitaalinen pelaaminen alkoi kohdallani 1980-luvun alussa, kun Nintendon Game \& Watch -"elektroniikkapelit" ilmestyivät markkinoille ja sieltä kaveripiiriimme. "Elektroniikkapeli" oli todellakin nimitys, joilla pelit tunnettiin. Samoihin

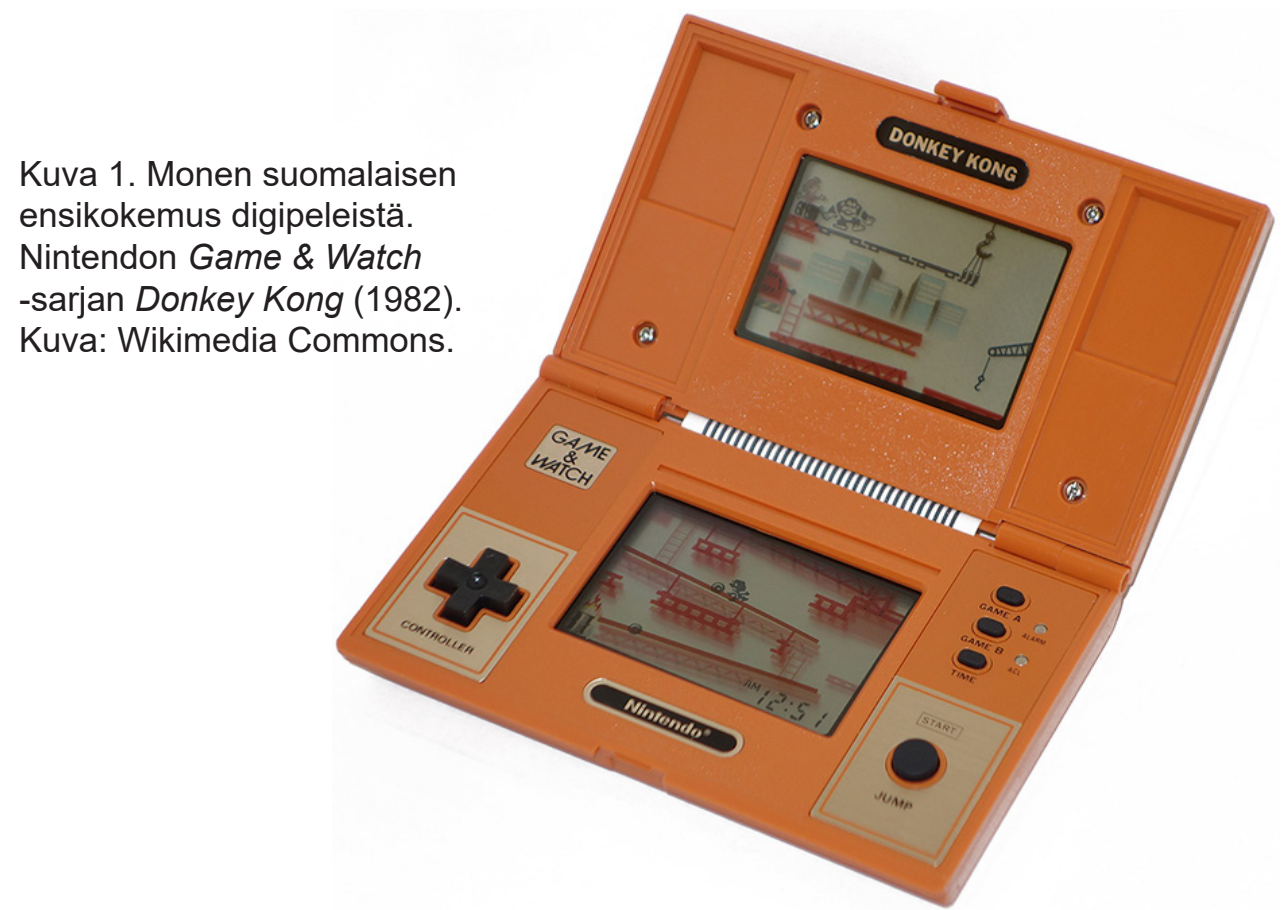


aikoihin naapurustoon alkoi ilmaantua ensimmäisiä kotitietokoneita (mieleen on jäänyt erityisesti kuminäppäimistöinen Spectrum). Myös niissä oli pelejä. Commodore 64 löi "tietokonepelit" lopullisesti läpi niin levinneisyyden, pelien määrän kuin pelikokemuksen tasoilla.

PC-aika nosti ne edelleen uusiin korkeuksiin, ainakin myöhäisteinin/nuoren aikuisen mielestä, joka 1990-luvun ensimmäisellä puoliskolla olin. Jääkiekon harrastajalle ja fanille EA Sportsin NHL-jääkiekkopelit, joista kirjoitan tämän numeron katsauksessani, olivat häkellyttävän jännittävä ja adrenaliinitasoja nostattava kokemus. Monilla oli Segan tai Nintendon pelikonsoli, mutta itse pelasin niitä lähes poikkeuksetta PC:llä (toinen suuri suosikki ajalta oli Doom jatkoversioineen). Opiskelujen myötä "tietokonepelaaminen" jäi pitkäksi aikaa ja hiipui myöhemmin kokonaan.

Käytän myös tietokonepelien kohdalla lainausmerkkejä, sillä kukaan tuntemani henkilö ei puhunut digitaalisesta pelaamisesta, enkä muista termiin törmänneeni ennen 2000-lukua. Digitaalipeleistä ei puhuttu myöskään "kännykkäpelien" kohdalla, joista epäilemättä yleisin oli Nokian matkapuhelimiin sisältynyt "matopeli" (Snake, 1997, suunnitellut Taneli Armanto), joka kulki maailmalla noin 400 miljoonan ihmisen taskussa (Tilt 2014). Tuolloin ei myöskään ainakaan yleisesti puhuttu vielä mobiilipelaamisesta, mikä liitetään älypuhelimien ja tablettien aikakauteen ja erityisesti päättyvässä olevan vuosikymmenen konseptiksi. Pelaan harvakseltaan mobiilipelejä älypuhelimella (yleisimmin mainituista NHL-peleistä johdettua jääkiekkopeliä). On mahdoton sanoa, pelaisinko lainkaan, mikäli minulla ei olisi historiaa digitaalisesta pelaamisesta vuosikymmenien ajalta - olkoonkin kuinka sporadista.

Epäilemättä Tilastokeskuksen tutkimuksessa mainitut lukuisat yli 44-vuotiaat ovat laillani tavalla tai toisella kasvaneet digipelaamiseen, vaikka asiaa ei nosteta esiin. Entä sitten tutkimuksen vanhin ikäryhmä, yli 65-vuotiaat? Heidän keskuudessaan vähintään kerran vuodessa pelaaminen on mainitulla 25 vuoden jaksolla noussut parista prosentista yli 20 prosenttiin. Prosentuaalinen nousu on ylivoimaisesti suurin ikäryhmistä. Osa tästä selittyy rahapelien pelaamisella, mutta tuskin kaikki. Digipelaamisen suosion on helppo uskoa kasvavan edelleen kaikissa ikäryhmissä. Lapset kasvavat pelikulttuuriin sisään alle kouluikäisestä alkaen.

Raine Koskimaan artikkelin aiheena on kansainvälisesti erittäin suositun Valtaistuinpeli-tv-sarjan (Game of Thrones, 2011-2019) pääosin YouTubessa julkaistut Let's Play -videot. Hän lähestyy niitä transmediauniversumin näkökulmasta, joka on keskeinen pelikulttuureille nykyaikana. Let's Play -videot tarjoavat hedelmällisen aineiston pelien ja yleisemmin populaarikulttuurin synnyttämien kokemusten tarkasteluun, sillä niiden kautta niin videoiden tekijät kuin fanit pohtivat moraalisia valintojaan suhteessa elämänkokemuksiinsa. Pelaaja-kertojien näkemysten ja videoiden kommenttiosioiden kautta päästään pohtimaan laajemmin toimijuutta ja vastaanottoa peli- ja populaarikulttuurissa ylipäätään.

Riikka Turtiainen tarkastelee artikkelissaan suomalaisten YouTuben ASMR (Autonomous Sensory Meridian Response) -roolileikkivideoita leikkikulttuurin ja leikintutkimuksen viitekehyksessä. Hän lähestyy ilmiötä haptisuuden ja kehollisen kokemuksen konteksteissa. Kysymys on roolileikeistä videolla esiintyvän artistin ja videon katsojan välillä. Videoilla on aistiärsykkeitä, triggereitä, jotka tuottavat osalle ihmisistä tahdosta riippumattomia, miellyt- 
täviä ja rauhoittavia aistielämyksiä. Digitaalisen kosketuksen voi hahmottaa muodostuvan aistien synestesian, kehollisen tietämisen ja mielikuvituksen yhteisvaikutuksesta.

Lasse Hämäläinen pureutuu artikkelissaan pelisivusto Aapelin Minigolfpelin (2002) tiiviin, yli 15 vuotta koossa olleen peliyhteisön kulttuuriin ja erityisesti siihen, miten käyttäjänimet ovat digitaalisissa ympäristöissä osa käyttäjien verkkoidentiteetin rakentumista. Etunimiä ja erilaisia tilapäisiä kutsumanimiä käytetään etenkin kielellisen leikittelyn sekä puhujan ja nimen kantajan välisen läheisen suhteen osoittavassa funktiossa. Etunimien käyttö sukunimien sijasta Minigolfin suomalaisista miehistä koostuvassa harrastajayhteisössä saattaa kertoa uudenlaisen maskuliinisen kulttuurin muodostumisesta.

Jaakko Suomisen katsaus kartoittaa suomalaisen pelaamisen historiantutkimusta ja toimii näin tärkeänä kokoavana tekstinä tälle teemanumerolle. Hän vetää merkkipaalun vuoteen 2009, johon asti tutkimukset julkaistiin pitkälti suomeksi, suomalaiselle yleisölle. Tässä vaiheessa ne olivat pääosin yleisesityksiä ja tietokoneharrastamiseen keskittyviä. Myöhemmin digitaalista pelaamista käsittelevä tutkimus on lisääntynyt, laajentunut ja kansainväistynyt, unohtamatta kansallisten ja paikallisten erityispiirteiden ja vertailevan tutkimuksen tarvetta.

Miia Siutila tarjoaa puolestaan vertailukohdan suomalaiselle pelitutkimukselle. Hän luo yleiskatsauksen korealaiseen pelitutkimukseen. Tarkemmin kyse on Etelä-Koreasta, joka on pelaamisen ja peliteollisuuden merkittävä tekijä. Maa e-urheilumenestyksineen toimii stimuloivana verrokkina vaikkapa Suomelle, sillä toiminta on pitkälle ammattimaistunutta. Pelaamisella ja erityisesti sen tutkimuksella on vahva yhteiskunnallinen ulottuvuus, sillä tutkimus on vahvasti ongelmalähtöistä - näkökulma, joka länsimaissa jää usein marginaaliseksi.

Rami Mähkän katsaus kohdentuu yhteen Suomen suositummista digipeleistä, eli EA Sportsin 1990-luvun alusta tuottamaan NHL-jääkiekkopelien sarjaan. Omilla ansioillaan tähtistatuksen hankkineesta Jeremy Roenickista tuli edelleen kulttimainetta nauttivan NHL 94 -pelin ohjelmoijien ansiosta legenda tavalla, johon hänen oman peliuransa saavutukset eivät olisi riittäneet. Mähkä liittää tämän ilmiön osaksi laajempaa identifioitumista virtuaaliurheilupeleissä.

Hyvä Lähikuvan lukija, toivon nautinnollisia ja inspiroivia lukuhetkiä numeron artikkelien parissa, rauhallista joulua sekä onnellista uutta vuotta 2020.

Turussa joulukuussa 2019

Rami Mähkä

\section{Lähteet}

Tilastokeskus (2019), Digitaalisten pelien pelaaminen nelinkertaistunut 25 vuodessa. Saatavilla: <http://www.stat.fi/til/vpa/2017/02/vpa_2017_02_2019-01-31_kat_001_fi.html> (linkki tarkistettu 2.12.2019).

Tilt (2014), Matopeli ei kuole koskaan. <https://www.tilt.fi/uutiset/yli-400-miljoonasta-nokiapuhelimesta-loytyvan-alkuperaisen-matopelin-suunnittelija-tekee-paluun-moderni-matopelion-tosiasia/> (linkki tarkistettu 3.12.2019). 